REGARDS

SUR LECONOMIE ALLEMANDE

BULLETIN ECONOMIQUE DU CIRAC

\section{Regards sur l'économie allemande}

Bulletin économique du CIRAC

$76 \mid 2006$

Varia

\title{
Grands classiques
}

SCHUMPETER Joseph, Theorie der wirtschaftlichen Entwicklung.

Nachdruck der 1. Auflage von 1912. Herausgegeben und ergänzt um eine Einführung von J. Röpke und O. Stiller

\section{(2) OpenEdition}

Édition électronique

URL : http://journals.openedition.org/rea/478

DOI : $10.4000 /$ rea. 478

ISBN : 978-2-8218-0848-5

ISSN : 1965-0787

Éditeur

CIRAC

Édition imprimée

Date de publication : 1 mai 2006

ISSN : 1156-8992

Référence électronique

"Grands classiques », Regards sur l'économie allemande [En ligne], 76 | mai 2006, document 3, mis en ligne le 24 avril 2008, consulté le 22 septembre 2020. URL : http://journals.openedition.org/rea/478 ; DOI : https://doi.org/10.4000/rea.478

Ce document a été généré automatiquement le 22 septembre 2020.

(c) CIRAC 


\section{Grands classiques}

SCHUMPETER Joseph, Theorie der wirtschaftlichen Entwicklung. Nachdruck der 1. Auflage von 1912. Herausgegeben und ergänzt um eine Einführung von J. Röpke und O. Stiller

\section{RÉFÉRENCE}

SCHUMPETER Joseph, Theorie der wirtschaftlichen Entwicklung. Nachdruck der 1. Auflage von 1912. Herausgegeben und ergänzt um eine Einführung von J. Röpke und O. Stiller, Duncker \& Humblot, Berlin, 2006, 548 p.

1 Voilà une réédition commentée de l'édition originale du grand ouvrage de SCHUMPETER telle qu'elle avait été publiée en 1912. On y trouve notamment un chapitre de l'édition originale, non réédité depuis lors (le $\left.7^{\mathrm{èm}}\right)$, consacré à « la vision globale de l'économie ». La réédition intégrale de cette œuvre majeure de la pensée économique dans laquelle l'économiste autrichien met pour la première fois en avant le rôle déterminant de l'initiative entrepreneuriale et du processus de «destruction créatrice » de l'innovation dans la dynamique économique vient à point nommé pour nourrir la réflexion actuelle sur les politiques d"innovation et l'émergence de l'économie de la connaissance. (rl) 